\title{
Examining the Achievements of the Balanced Scorecard as Public Sector Reform Tool: The Case of Some Selected Oromia Regional Government Bureaus
}

\author{
Assefa Abu Geru \\ Lecturer at Oromia State University, Ethiopia
}

\begin{abstract}
Ethiopian government has shown commitment to improve public service delivery in public organizations by launching different reform tools under the scope of civil service Reform Program. However, public service organizations performance has a number of deficiency in terms of effectiveness and efficient. Therefore, the objective of this study was to examining the achievements of the balanced scorecard (BSC) as public sector reform tool in some selected oromia regional government bureau. A descriptive survey type and both quantitative and qualitative approaches of data analysis were employed. The quantitative data was drawn from sampled 150 employees for questionnaires purpose by using probability sampling technique. Then the analysis of the quantitative data were made using descriptive statistics such as frequency, percentage, cross tabulation, bar chart, Pearson chi-square test and spearman's rho correlation were used. The qualitative data was obtained through interview, focus group discussion and document analysis. The study revealed that due to implementation of Balanced scorecard the bureaus performance were measured from citizens, financial, internal process and learning and development perspectives and evaluation system were improved and strategic objectives of the organizations were linked to the objectives of department, teams and individuals.. On the contrary, the findings of the study indicated majority of employees viewed as implementing Balanced scorecard as duplication of business process reengineering(BPR) . Moreover, the implementation of balanced scorecard in selected bureaus faced lack of leadership support and commitment, lack of capacity building, poor communication, low information communication technology skills and poor monitoring and evaluation. Hence, the reality of the concepts and goals needs to internalize and play their active role in leading changes through implementation of balanced scorecard as solution to make the public sector effectiveness and efficient.
\end{abstract}

Keywords: - Balanced scorecard, performance measures, reform Tools

DOI: $10.7176 / \mathrm{PPAR} / 10-3-02$

Publication date:March $31^{\text {st }} 2020$

\subsection{INTRODUTION}

The modern public service in Ethiopia dates back to 1907 when nine of ministers were established, with an objective of ensuring orderly and efficient arrangement for the workings of governments (MoCS, 2012). Later emperor Haileselase I introduced various reform measures in modernizing public administration and in the appointment of salaried and educated personnel in the public service based on the criteria of loyalty to the monarch and their family status rather than merit (Tilaye, 2007). These were characterized by inadequate structures, inefficient services, corruption, political interference, and the interference of nobility in the due process of law in matters of public concern for their privet wellbeing (MoCS, 2012). High regard given to political interference affecting standard operating producers, the public service failed the intended service to the public (ibid)

The dergue regime (1974-1991) continued the centralization policy of the emperor and seriously affected the development and professionalism of the civil service (Tilaye, 2007). Generally, the civil service during the emperor Hailesesie, and Dergue regime was not natural policy implementer, responsive to the people's interest, impartial, transplant and accountable, among others, the public service, as an institution was not loyal to the public. The institutions and the mindset of the workers and public servants were operated against the long lasting development of the country after the downfall of the dreg regime (since 1991), the current government of the federal democratic republic of Ethiopia has been taking some encouraging initiatives and reforms in economic, political and sociocultural aspects against undemocratic and backward public service delivery systems in the past regimes. The comprehensive civil service reform program(CSRP) was therefore formulated on five major sub-programs. These are top management system, human recourse sub program, expenditure and control sub program, expenditure management and control sub reform, ethics sub reform programs that have been widely under implemented in oromia in particular and country in general (Hagerbigegn\& Baro, 2016).

The reform program, in its implementation phase so far, has taken into place the following basic public service reforms tools: Among these are Business process Reengineering (BPR) Balanced Scorecard (BSC) and change army which considered as reform tools to implement in integral to improve public organization efficiency and effectiveness in Ethiopia (MOCS,2012). Performance measures are an important aid to improve performance in all aspects of a given organization. In this sense, unless a given organization measures and manages its 
performance, it is difficult to control its performance. Balanced scorecard is one of the performance measures and manages employees performance which enables an organizations to translate its vision and strategy in to a tangible set of performance measures by integrating financial measures with customer, internal business and organizational growth and learning perspectives (Kaplan \& Norton, 1996).As a result the balanced scorecard management tool has been introduced over the last ten years. One of the rationales for undertaking this particular study was curiosity to check the effectiveness of the balanced scorecard at selected oromia regional state bureaus.

\subsection{STATEMENT OF THE PROBLEM}

Balanced scorecard (BSC) is one of the management tools that recently undertaking in government public organizations. The BSC was developed by Robert Kaplan \&Norton in 1992 as an alternative to traditional performance measurement approaches that focus solely on financial and are based purely on organization past performance. It can be defined as a strategic planning and management system that is used to arrange organizations activities based on the vision and strategy of the organizations, to make effective internal and external communication processes and to monitor and improve organizations performance against the overall strategic goal( Kaplan\&Norton,2010). Balanced scorecard is considering not only the financial results which are important, but also those factors which actually drive business towards future success. Moreover, the balanced scorecard exerts a tension to other areas in order to provide, balance and improve total view about the financial performance (Evans,2002). Properly understood and implemented BSC tool beings a number of benefits. By the authors of the BSC( Kaplan\&Norton,2007) is the major contribution of BSC mainly the fact that it helps the organizations to implement the vision and strategy in to objectives and measurements. The BSC links the vision and the strategy of the organizations with daily decision making process and facilitates the communication and understanding of the strategy across the business and helps to align the individual goals of the employees with the organization objectives. In relation to this Ethiopia government was introduced BSC in 2008 as a performance measurement and management tool with objectives to achieve effectiveness and efficiency of the various aspects at the federal and regional levels through radical transformational measures. From this some positive results have been achieved. However, mere designing the Balanced scorecard tool do not yield the intended results. As indicated by (Kaplan\&Norton,2010) the organizations have to continuously develop a new mindset so as to manage and lead the changes. Because the effectiveness of organizational performance are also uneven and have large variations among the Bureaus and low citizens satisfaction in service delivery. This fact indicated that the BSC tool designed to measure effectiveness and efficiency of the organizations and the bureaus putting on the top satisfaction of their citizens were not achieved at the speed that government and citizens expected. Such manifestations of gaps are not to be undermined that actually initiated the researcher to examining the achievements of the balanced scorecard (BSC) as public sector reform tool in some selected oromia regional government bureaus.

\subsection{Objectives of the Study}

The major objective of this study was to examining the achievements of the balanced scorecard (BSC) as public sector reform tool in some selected oromia regional government bureaus.

Specific Objectives

1. To analyze the achievements of Balanced scorecard in some selected oromia regional government bureaus.

2. To assess the leaders and employees perception towards Balanced scorecard implementation some selected oromia regional government bureaus.

3. To identify the major challenges of Balanced scorecard implementation in some selected oromia regional government bureaus.

\subsection{Research Questions}

1. To what extent the achievements of Balanced scorecard some selected oromia regional government bureaus?

2. How leaders and employees perceived towards Balanced scorecard implementation in some selected oromia regional government bureaus.?

3. What are the major challenges of Balanced scorecard implementation in some selected oromia regional government bureaus.

\subsection{LITERATURE REVIEW}

\subsection{The Genesis of Public Service Reform in Ethiopia}

\subsubsection{The Imperial Era of Ethiopia Public Service Reform}

The country of Ethiopia has its own distinctive institutional features and traditions that determine the functional and structural development and characteristics of its civil service. The making of its modern statehood goes back to "the mid-nineteenth century when different regions were gradually reintegrated to form the nucleus of a modern state by strong monarchs'. Of these monarchs, it was during the reign of Emperor Minilik II (1889-1914) that the modern administrative system in Ethiopia was established with the formation of the first cabinet on 25 October 
1907 (Marcus, 1994:110).

The cabinet comprised of ministries of war, justice, pen (performing duties and responsibilities related to state public relations), finance, commerce and foreign affairs, agriculture, public works, and the ministry of the imperial court (Zewdie, 1991:153). There was no specific administrative agency to deal with public human resources as the council was intended to strengthen the imperial foundation, expand the power of the sovereign and ensure the continuity of the imperial state (ibid). A year later, in achieving these objectives, the Emperor introduced, among others, the first educational institution in his name Minilik II School in the capital city, Addis Ababa (Adejumobi, 2007:33).

The last monarch after Emperor Minilik, Hailesilassie I, also pushed forward the agenda "to educate the elite as he believed that the effect of education would transform his feudal empire into a modern state" (Marcus, 1994:160). He attempted to strengthen the national government by introducing a new generation of educated Ethiopians into new and enlarged ministries. The first written constitution for Ethiopia was introduced and a bicameral legislature with a senate and a chamber of deputies was established for the first time in the history of the country during the reign of Emperor Hailesilassie in 1931 (Adejumobi, 2007:54). The Emperor also introduced major structural reforms that included professionalization of the bureaucracy, and ordered for the establishment of the first administrative agency, but were poorly staffed with educated personnel, and rules and regulations approved to process major functions that were related to human resource management were frequently abused by the ministers and other high officials (Paulos, 2001:80).

\subsubsection{The Socialist Era of Ethiopia Public Service Reform}

With the end to the imperial administration in 1974, the political system and economic structure of Ethiopia were dramatically changed towards a socialist system where the activities of the country were to be guided through a central plan (Ofcansky, 2004:163). Consequently, Office of the National Council for Planning (ONCCP) chaired by the head of state, Colonel Mengistu Hailemariam, was given the power and responsibility to prepare the directives, strategies and procedures for all plans (ibid).

However, highly politicized to the extent that it routinely by-passed the basic laws it established to support its own system (Taffesse, 2008:397). The (ADB, 2009:4) reports that the quality of the Ethiopian public administration during the times of both the imperial and military regimes was characterized by "a highly centralized and control oriented civil service".

\subsubsection{The Ethiopian People Revolutionary Democratic Era of Public Service Reform}

It was only since the launching of the Civil Service Reform Programme in 1994 that the performance incompetence of public servants was mentioned for the first time since the Emperial Era (Adebabay, 2011:6). Due to the capacity problem being experienced, government services in Ethiopia rarely if ever address the basic needs of the public (UNECA, 2009:170).

The Ethiopian government "has articulated democratic developmental state as its policy to take center stage in Ethiopia" (Fiseha, 2014). Accordingly, the state needs to have the required policy and state (strategic) capacities, and administrative (organizational and technical) capacity attained through building a strong civil service (ETU, 2013).

This was further emphasized when the Ethiopian Growth and Transformation plan (GTP) was launched in 2010 that called for superior organizational performance through the mobilization of professional employees, including those in the civil service (Adebabay, 2011:9). Civil service reform is a result of a credible government's interest in improving the performance of public service institutions; and it is a deliberate change for the design and delivery of public services (Boyne. A, 2000 as cited in Tilaye, 2007:11).

The Civil Service Reform Program has a grand objective of transforming the public Service through addressing the key challenges that hinder the performance of the public Service and enhancing the capacity. The program seeks to achieve effectiveness and efficiency of the various aspects at the Federal and regional levels through radical transformational measures. So far, quite numerous attitudinal, structural and systemic changes have been conducted and through these significant positive results have been observed.(MoCS,2012). Therefore, $\mathrm{BSC}$ is one of the tool exercised to realize the purpose of service delivery sub-program.

\subsection{Conceptualization of Balanced Scorecard (BSC)}

The Balanced Scorecard is considered as a management system that provides a ground for businesses to clarity their vision and convert them into action. BSC is a management system (not only a measurement system) that enables organizations to clarify their vision and strategy and translate them into action (Kaplan \& Norton, 1996). According to (Niven, 2006) defined BSC as "Balanced Scorecard is a carefully selected set of quantifiable measures derived from an organization's strategy, that measures selected for the scorecard represent a tool for leaders to use in communicating to employees and external stakeholders. In similar way BSC defined as the outcomes and performance drivers by which the organization will achieve its mission and strategic objectives in the eyes on financial, customer, internal process and internal growth and development perspective" there are several authors that in their work deal with BSC method in the strategic business management and with 
identification of problems emergency through its implementation in business (De Waal, 2013). As stated by the authors of the BSC (Kaplan \& Norton, 2007) the method mainly the fact that it helps businesses to implement the vision and strategy into objectives and measurements, connects the vision and the strategy with daily decision making process, facilitates the communication and understanding of the strategy across the businesses and helps to align the individual goals of the employees with the business objectives. The authors argue that the measurements in the BSC should serve mainly as an aid in formulating the corporate strategy, its communication and the mutual alignment of individual and corporate initiatives and departmental initiatives towards the achievement of the common goal. In similar way, (Balanced Scorecard Institute, 2012) can be summarized, that BSC can help, to increase focus on strategy and results, to break the communication noises between departments, to increase understanding of customer needs and flexibility to respond to them, to improve businesses performance by measuring the important areas, to assist the management in making better decision based on analysis of relevant performance indicators, to assist the management with more effective planning of the time and resources, to assist the management and employees to concentrate on important tasks.

\subsection{Achievements and challenges of the Reform Tools in Ethiopia}

Based on the documented information produced by the World Bank issued on 2013, it states that around 145 federal and 270 regional offices in Ethiopia have implemented BSC; the institutions have integrated balanced scorecard measures in their strategic plans.

According to (Fikadu, 2009) recommended that Commercial bank of Ethiopia is better utilize BSC approach for its performance management in addition to traditional approach because BSC measures performance of the business taking in to account the long run aspects of the business like Customer satisfaction, internal business process and learning and growth perspective of the business rather than only dwell on financial matters. As (Tesfaye \& Ataklity 2011:149-150) stated absence of reward system and low level of salary in public organization especially in civil service adversely affected employee motivation and caused high labor turnover.

Similarly, lack of ICT infrastructure and its utilization skill, weak monitoring and evaluation, gaps in understanding why and where to implement the reform tools and absence of clear and uniform measurement and incentive system and unchanged attitudes of employees and leaders were some of the challenges to successfully implement the reform tools in the country in general and in the Oromia region in particular for the successful implementation of reform tools in the Oromia Regional State (PSCO, 2015).

\section{CHAPTER THREE \\ RESEARCH METHODOLOGY}

\subsection{Research Design and Approaches}

The research type was employed descriptive survey. The survey method on other hand is an appropriate technique that is usually used to collect data through questionnaires and interview (Kothari, 2004). In this study the researcher has applied both quantitative and qualitative research approaches popularly called mixed methods which helps to collect two different types of data simultaneously, that aiming to answer both how and why questions systematically. Such an approaches also provides a more complete and comprehensive picture of the study by offsetting weaknesses of the other so as to collect and analyze both data to address the research questions.

\subsection{Population of the Study}

The population of this study was all permanent public servants governed by Federal civil servants proclamation 213/2011 (employees and leaders) in selected oromia Bureau

\subsection{Sampling Techniques and procedures}

The researcher selected Urban land administration and uses Bureau, Housing and Urban Development Bureau, Finance and Economic development Bureau, Oromia Revenues Authority, Oromia trade Bureau purposively selected for the study because they are consider as poverty reduction sectors and serves many citizens relatively than others bureau while Public service and Human Resource Development Bureau is the leading institution of the reform tools in the region again selected purposively. However, respective Bureaus employees have been selected through simple random sampling were incorporated on their proportion. One focus group discussant that have 12 members and sampled organization leaders were selected purposively for interview based on their job relevancy.

\subsection{Sample size}

The sample was determined according (Yamane ,1967:886) provides a simplified formula to calculate sample sizes by the formula $\mathrm{n}=\mathrm{N} / 1+\mathrm{Ne}^{2}$ sample proportion of each employees, $\mathrm{n}=$ sample size, $\mathrm{N}=$ the size of population $\mathrm{e}=$ the margin of error the level of confidence require $95 \%$ confidence level. Therefore, based on the above formula, the public servants sample was calculated as follows: $n=241 / 1+241(0.05 \times 0.05)=150$ 
Hence, the obtained sample of public servants by the above formula were distributed to sample organizations based on their proportion(numbers of public servants in office $\mathrm{x}$ the calculated sample size(150) divided to total population and respected leaders from sampled organizations were taken purposively based on their job relevancy. The sample distribution was shown as follow.

Table 3.1: Distributed and Collected Questionnaires per Sample Organizations

Type of Public sectors

Urban land administration and uses Bureau

Finance and Economic development Bureau,

Housing and Urban Development Bureau

Oromia Revenues Authority

Oromia trade Bureau

Public service and Human Resource 26

Development Bureau

Total

Source: Field survey,2019

Thus, for total 156 population, questionnaires were distributed to employees $150(96 \%)$ questionnaires that were properly filled and returned.

\subsection{Data Sources and Data Collection tools}

For this study both quantitative and qualitative type of data were employed. With regard to data sources both primary and secondary sources of data were used. The primary sources of data were collected through questionnaires, interview, focus group discussion from employees and respective sampled bureau heads and Secondary data were obtained from different sources such as ,articles, journals, annual report on human resource profile of the bureaus. It was assumed that reviewing these things may help the researcher to gather more information with regard to public service reform tools implementation

\subsection{Validity and Reliability}

To approve the reliability and validity of questionnaires before dispatching to the targeted population the draft of questionnaires were developed and distributed $20 \%$ of the sample size which is 30 employees of transport agency and youth, children and women Bureau were used. Because, those have similar characteristics to the actual targeted study to ensure appropriateness and correctness of the items included .In addition to this after qualitative type of data entered to SPSS version 21 the questionnaires reliability also checked by cronbach's alpha .As a result computed value was 0.866 . This shows that the items were consistence to measure.

\subsection{Data Analysis tools}

Data collected for this study were checked from collection to data entry before they ready for analysis. At the beginning the data collected from all sources were checked and organized with respect to basic research questions and objectives of the study. Then they were analyzed quantitatively and qualitatively. The quantitative data were processed using statistical package for social science (SPSS version 21). Then the analysis of the quantitative data were made using descriptive statistics such as cross tabulation ,frequency, percentage, bar chart, Pie chart, and Spearman's rho. The data collected from interviews, focus group discussion and open ended questionnaire were also put in to code and transcribed into texts and analyzed using content analysis or exploratory means. Subsequently, the results obtained both from qualitative and quantitative data are mix to compare the results through triangulation, explanation, comparison, and identification of relations among the data sources in relation to the research questions.

\section{CHAPTER FOUR \\ RESULTS AND DISCUSSION}

\subsection{Introduction}

The purpose of this study was to examining the achievements of the balanced scorecard (BSC) as public sector reform tool in some selected oromia regional government bureaus.

This chapter presented an analysis and discussion of the results of a survey that was administered to 150 respondents and discussion were held with 6 interviewees, as well as 12 employees focus group discussants that male and female were participants within Bureaus

This study was guided by three research questions.

1. To what extent the achievements of Balanced scorecard some selected oromia regional government bureaus?

2. How leaders and employees perceived towards Balanced scorecard implementation some selected oromia 
regional government bureaus?

3. What are the major challenges of Balanced scorecard implementation some selected oromia regional government bureaus.

The answers to the research questions were derived by analyzing the results from the survey that was completed by the study participants. The analysis and interpretation of the data collected from selected oromia regional Bureaus leaders and employees through questionnaires, interview, focus group discussion and secondary data reviewed with respect to Balanced scorecard tool theories and concepts. Consequently, based on the responses obtained from the sampled respondents analyses and interpretation of the data are presented subsequently as follow.

\subsection{Characteristics of Respondents}

Table 4.1:Sex, Age, Education level and Service Years of Respondents

\begin{tabular}{|c|c|c|c|}
\hline & \multicolumn{3}{|c|}{ Public servants } \\
\hline & & Frequency & Percent \\
\hline \multirow[t]{3}{*}{ Sex of respondents } & Male & 99 & 66 \\
\hline & Female & 51 & 34 \\
\hline & Total & 150 & 100 \\
\hline \multirow[t]{5}{*}{ Age of Respondents } & $18-25$ & 15 & 10 \\
\hline & $26-35$ & 79 & 52.7 \\
\hline & $36-45$ & 39 & 26 \\
\hline & 46 \&above & 17 & 11.3 \\
\hline & Total & 150 & 100 \\
\hline \multirow{7}{*}{$\begin{array}{l}\text { Educational } \\
\text { respondents }\end{array}$} & 12 or 10 completed & 4 & 2.7 \\
\hline & Certificate & 2 & 1.3 \\
\hline & Diploma & 31 & 20.7 \\
\hline & $1^{\text {st }}$ degree & 106 & 70.7 \\
\hline & $2^{\text {nd }}$ degree & 6 & 4 \\
\hline & Others & 1 & 0.7 \\
\hline & Total & 150 & 100 \\
\hline \multirow[t]{6}{*}{ Service years of public servants } & Below 5 years & 41 & 27.3 \\
\hline & $6-10$ years & 40 & 26.7 \\
\hline & $11-15$ years & 26 & 17.3 \\
\hline & $16-20$ years & 10 & 6.7 \\
\hline & $21 \&$ above & 33 & 22 \\
\hline & Total & 150 & 100 \\
\hline
\end{tabular}

Source: Field survey,2019

As it can be seen from the table 4.1 above, female public servants were 51(34\%) in bureaus when compared with male $99(66 \%)$. From this simple we can understand that male and female were participated in the study with different proportions.

As a productive age group, the expectations from young professionals are to accept and adopt new technologies easily being flexible and providing quality service in a timely manner among other things. In this regard, currently of the public servants in selected bureaus, the majority $79(52.7 \%)$ of the public servants are between the age of $25-35,39(26 \%)$ were between $36-45$ and the remaining $15(10 \%)$ were between $18.5-25$ and17(11.3\%) were 46\&above The dominance of this productive age group appears to be true for both sexes. As young professional are more provocative and agile enough to welcome new change initiatives implementation. The bureaus are positioned well given its rich population of young public servants to implement the public service reform tools, if only managed properly. This show that the respondents were from variety of age groups to provide a comprehensive information based up on their experiences.

As it can be indicated, in summery of table 4.1 above ,majority $106(70.7 \%)$ of the respondents were first degree holders,31(20.7\%)of public servants have diploma. Thus, they can easily understand the purpose of the study and give reasonable response to survey items.

Regarding work experience 41(27.3\%) of respondents have below five years of work experience, $40(26.7 \%)$ have work experience between 6-10 years,26 (17.3\%) have $11-15$ years , 10(6.7\%) have 16 to $20 \%$ years and $33(22 \%)$ of respondents have 21 and above work experience. This indicated that respondents of different experiences were participated in the study.

\subsection{The implementation of Balanced scorecard Tool in Public service}

To solve deep-rooted problems of service delivery practices in the public organizations, the government of Ethiopia designed and implemented various reform tools after launching the service delivery policy of 2001. Such 
reform tools are BPR,BSC and Change army are some of the tools exercised in all country public organizations in general, particularly in Oromia . Administration on to realize the purpose of service delivery sub-program. In relation to this view the following tables shows the responses of respondents on balanced scorecard reform tool implementation in selected oromia bureaus for this study purpose.

Table 4.3 : Respondents Knowledge of the BSC tool in public organization?

\begin{tabular}{|c|c|c|c|c|c|c|c|c|}
\hline & & \multicolumn{6}{|c|}{ Knowledge of BSC tool by employee of Batu town } \\
\hline & & & $\begin{array}{l}\text { yes, we know } \\
\text { exactly the } \\
\text { BSC tool\& } \\
\text { implemented } \\
\text { in office }\end{array}$ & $\begin{array}{l}\text { yes, we } \\
\text { now but } \\
\text { we don't } \\
\text { utilize } \\
\text { the BSC }\end{array}$ & $\begin{array}{l}\text { We don't } \\
\text { now }\end{array}$ & $\begin{array}{l}\text { We know } \\
\text { how, but we } \\
\text { would like } \\
\text { to learn } \\
\text { more }\end{array}$ & $\begin{array}{l}\text { No } \\
\text {,we are } \\
\text { even not } \\
\text { interested } \\
\text { because } \\
\text { we use } \\
\text { other tool }\end{array}$ & Total \\
\hline \multirow{5}{*}{ Total } & Male & Count & $\begin{array}{l}5 \\
51 \%\end{array}$ & 15 & 32 & $\begin{array}{l}38 \\
384 \%\end{array}$ & $\begin{array}{l}9 \\
91 \%\end{array}$ & $\begin{array}{l}99 \\
1000 \%\end{array}$ \\
\hline & \multirow{2}{*}{ Female } & Count & & & & & & 51 \\
\hline & & $\%$ & $2.0 \%$ & $3.9 \%$ & $43.1 \%$ & $37.3 \%$ & $13.7 \%$ & $100.0 \%$ \\
\hline & & Count & 6 & 17 & 54 & 57 & 16 & 150 \\
\hline & & $\%$ & $4.0 \%$ & $11.3 \%$ & $36.0 \%$ & $38.0 \%$ & $10.7 \%$ & $100.0 \%$ \\
\hline
\end{tabular}

Source: Field survey,2019

As it indicated in the cross tab 4.3 above,57(38\%) of the respondents revealed that know how, but they were required to learn more the BSC tool while a considerable number of respondents $54(36 \%)$ were answered don't have knowledge of the BSC tool in implementation and 17(11.3\%) of the respondents replied as they have knowledge of BSC tool, but don't put in to practice . Both male and female were victims of the lack of required BSC knowledge in implementation. Though, 38(38.4\%) of the male respondents and 19( 7.3\%) of the female respondents were replied need to know more about BSC ,32(32.3\%) of the male respondents and 22(43.1\%) of the female respondents replied they do not have knowledge of BSC tool. This also confirmed by the focus group discussion and interview were conducted with sampled bureau leaders. They were described level of BSC tool knowledge and its implementation different from organization to organization as well as employees. Again focus group discussant stressed in some public organization implementation of BSC seemingly dominated by paper work involving more of superficial activities than what is in practice. While the participants reason out, some even consider the tasks of the BSC tool to be left to the expert of planners in the bureaus and were the leaders relays reports they receive. From this simple we can conclude that the knowledge of BSC tool were not at required level and less attention was given, still $4 \%$ of the respondents confirmed that indicated as exactly have the knowledge of the BSC tool\& implementing in their bureaus.

Figure 4.1: Respondents opinion in prioritizing most reasons for implementing BSC in organizations.

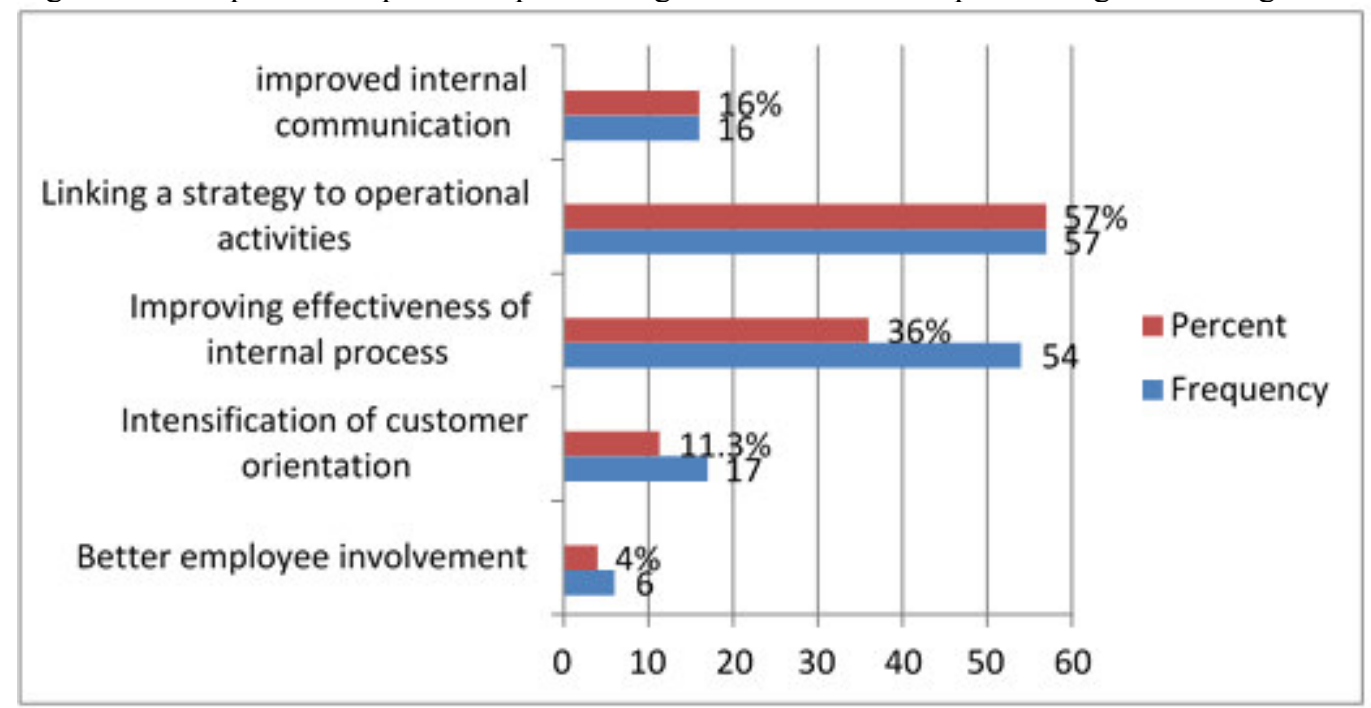

Source: Field survey,2019

As it can be seen from above figure 4.1, the respondents were indicated, one of other most reasons for implementing BSC tool is to linking a strategy to operational activities in every activities $(57 \%$ of the respondents),improving effectiveness of internal business process( $36 \%$ of the respondents),intensification of 
customers of organization(11.3of the respondents) and improved internal communication( $16 \%$ of the respondents) This show that implementing the BSC tool, in linking organizational strategy to daily activities. Nevertheless, less employee involvement were observed (4 of the respondents only prioritized)

Table 4.4: Assessment of some Achievement of BSC tool in some selected oromia bureaus

\begin{tabular}{|c|c|c|c|c|c|c|c|}
\hline Survey statement & & SD & $\mathrm{D}$ & $\mathrm{N}$ & A & SA & Total \\
\hline \multirow{2}{*}{$\begin{array}{l}\text { Linking the strategic objectives to the objectives } \\
\text { of department, teams and individuals }\end{array}$} & $\mathrm{F}$ & 5 & 14 & 50 & 67 & 14 & 150 \\
\hline & $\%$ & $3.3 \%$ & $9.3 \%$ & $33.3 \%$ & $44.7 \%$ & $9.3 \%$ & $100 \%$ \\
\hline \multirow{2}{*}{$\begin{array}{l}\text { BSC improving performance measurement and } \\
\text { evaluation of organization process }\end{array}$} & $\mathrm{F}$ & 3 & 24 & 8 & 57 & 58 & 150 \\
\hline & $\%$ & $2.0 \%$ & $16.0 \%$ & $5.3 \%$ & $38.0 \%$ & $38.7 \%$ & $100 \%$ \\
\hline \multirow{2}{*}{$\begin{array}{l}\text { The individual scorecard linked with rewards, } \\
\text { recognition and incentives }\end{array}$} & $\mathrm{F}$ & 11 & 64 & 25 & 43 & 7 & 150 \\
\hline & $\%$ & $7.3 \%$ & $42.7 \%$ & $16.7 \%$ & $28.7 \%$ & $4.7 \%$ & $100.0 \%$ \\
\hline
\end{tabular}

Source: Field Survey,2019

Note: Strongly Disagree(SD), Disagree(D), Neutral(N),Agree(A),Strongly Agree(SA

One of the importance of implementation of BSC is cascading organization plan to departments and individuals level. Align the organization through strategy, using the strategy map, performance measures and targets, and initiatives. In relation to this , as it indicated in the above table respondents were asked whether or not organizational strategic objectives linked to the objectives of department, teams and individuals objectives respondents, majority of $67(44.7 \%)$ of the respondents replied that there were the organizational strategic objectives of the organizations linked to the objectives of department, teams and individuals while a one third of participants 50(33.3\%) in doubt to decide the existing link of organizational strategic objectives to departments, teams and individual objectives. This shows that majority of the respondents believed implementation of BSC aligned departmental, teams, and individual objectives with the strategic objective of organizations.

Different study show that in Ethiopia in general, Oromia in particular, before BSC adopted as performance management and evaluation system, were used trait based performance appraisal, behavioral-based appraisal system. Thus, was also practiced during BPR implementation in public organizations which was not effective and efficient, but what currently get attention was application of strategic performance management system or performance management and evaluation system / BSC to sustaining positive result registered the BPR implementation. Resulting from the survey it was found that the main benefits of implementing the BSC tool is to improve performance measurement and evaluation system of organizational performance. Because, 58(38.7\%) of the respondents strongly agree,57(38\%) were disclose their agreement as BSC improving performance measurement and evaluation of organization process. Nevertheless, lacks of required knowledge about the BSC, the respondents were believed that performance measurement and evaluation system were improved due to implementation of BSC. Scorecards are used to improve accountability through objective and performance measure ownership(Balanced Scorecard Institute, a 2008). As we can see from above table, 64(42.7\%) of the respondents revealed their rejection to the individual scorecard link with rewards, recognition and incentives while considerable number of respondents 43(28.7\%) were accept the individual scorecard link with rewards, recognition and incentives and , 25(16.7\%) of the respondents were unable to decide the individual scorecard link with rewards, recognition and incentives. From the discussion simple we can concluded that ,lack of individual scorecard link with rewards, recognition and incentives decrease employee motivation towards achieving personal performance contributing to fulfilling strategic objectives of organization. 
Figure 4.2: Respondents opinion in prioritizing the most reasons of disinterest to the BSC tool

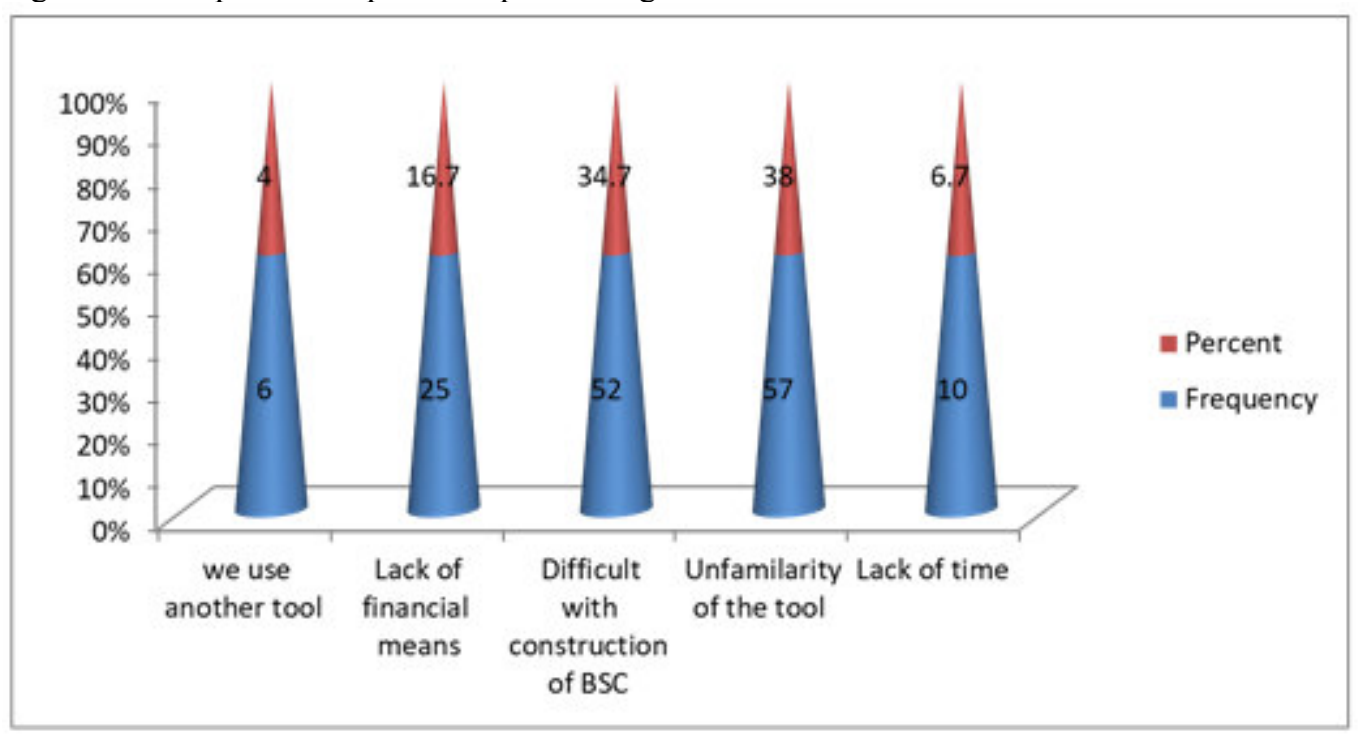

Source: Field Survey,2019

As it can be seen from above figure 4.2 the most common reasons for disinterest in implementation of BSC tool belong unfamiliarity with tool $57(38 \%)$ of the respondents while $52(34.7 \%)$ believed difficult with construction of BSC and 25(16.7\%) indicated lack of finance. This also reaffirmed by interview and focus group discussants were mentioned as they perceived implementation of BSC difficult and challenging. This directly related to lack of required knowledge of BSC tool earlier discussed. Though, employees need to be trained on the concept and its importance to implement in public organization. This can help the employees to have uniform understanding and utilization as performance management tool and reduce resistance to change management tools.

\subsection{Assessment of the challenges of Balanced score card Tool implementation}

Reforms are not risk-free. They can be supported or opposed by people depending on their point of view; may produce unintended results; may be difficult to implement; may generate the need for further reforms; or simply may not work at all endangering the survival and legitimacy of public organizations and its managerial and political leadership. Hence, one important aspect of reforms is the management of the change or effects produced by its implementation. This fact begs two questions: how to manage the change produced by a reform process, and what characteristics should a reform have so as to be manageable or effort to transform the way public organizations work and are managed. In relation to this view table depict some challenges observed in balanced scorecard implementation in sampled bureaus.

Table 4.5: Challenges to Balanced scorecard tool implementation in oromia bureaus

\begin{tabular}{|l|l|l|l|l|l|l|l|}
\hline Survey statement & & SD & D & N & A & SA & Total \\
\hline \multirow{2}{*}{ Poor communication } & $\mathrm{F}$ & 9 & 34 & 39 & 54 & 14 & 150 \\
\cline { 2 - 8 } & $\%$ & 6 & 22.7 & 26 & 36 & 9.3 & 100 \\
\hline \multirow{2}{*}{ Lack of leadership support and commitment } & $\mathrm{F}$ & 16 & 34 & 3 & 54 & 43 & 150 \\
\cline { 2 - 8 } & $\%$ & 10.7 & 22.7 & 36 & 28.7 & 2 & 100 \\
\hline \multirow{2}{*}{ Lack of skill gap analysis } & $\mathrm{F}$ & 5 & 12 & 60 & 58 & 15 & 150 \\
\cline { 2 - 8 } & $\%$ & 3.3 & 8 & 40 & 38.7 & 10 & 100 \\
\hline \multirow{2}{*}{ Lack of effective monitoring and evaluation } & $\mathrm{F}$ & 13 & 57 & 47 & 24 & 9 & 150 \\
\cline { 2 - 8 } & $\%$ & 8.7 & 38 & 31.3 & 16 & 6 & 100 \\
\hline
\end{tabular}

\section{Source: Field Survey,2019}

Note: Strongly Disagree(SD), Disagree(D), Neutral(N),Agree(A),Strongly Agree(SA)

Above table depicts that the respondents were consulted to share their opinion about BSC as communication tool , 54(36\%) of the participants of survey agree with poor communication while $34(22.7 \%)$ of the respondents were appreciated BSC as communication tool in the organizations. However, considerable numbers of respondents were not sure. Though, BSC reform tool implementation assist as communication tool with employees, customers and stakeholders. The result indicates the communication and awareness creation on the importance and how to implement BSC tool is not at the level it required. Due to lack of communication, however, confusion among employees have been common in public organizations. Many literatures indicated that, the effective implementation of public service reform tools needs leadership support and commitment. However, in practice, as it indicated in cross tab 4.5 item 2 above,54(36\%) and 43(28.7\%) of the respondents were rated agree and strongly 
agree with lack of leadership support and commitment in public service reform tools implementation while one third of the total respondents confirm the existence of leadership support and commitment during reform tools implementation. Similarly in the above table item 3 indicated that,even though the skill gap analysis before training is basically important requirement to fulfill the skill gap of employees in balanced scorecard implementation ,58(38.7\%) and 60(40\%) of the respondents stated that skill gap analysis was not conducted before training while $15 \%$ of the respondents were appreciated the existence of skill gap analysis in the bureaus. From this simple we can infer that the skill gap analysis provided to the public servant before training was poorly carried out. Therefore, the training unit needs to have up dated information concerning the knowledge and skill deficiency before providing training in bureaus. The results of a good planning are also ensured by the effective monitoring and evaluation system because the assessment results helps to bridge the gap between" Where we are and where we want to go"'(Hammer and Champy,1996). In spite of some positive achievements of balanced scorecard in selected bureaus for this study purpose low monitoring and evaluation were observed . For this reason, as shown in the table 4.5 above $57(38 \%)$ and $13(8.7 \%)$ of the participants rated as monitoring and evaluation of reform tools in public organization were low and very low respectively From this simple we can conclude that lack of monitoring and evaluation is still challenging the Balanced scorecard reform tool effectiveness in public organizations.

Table 4.6 Correlations of BSC with BPR and Change army members commitment in organization

\begin{tabular}{|c|c|c|c|c|c|}
\hline & & & $\begin{array}{l}\text { Implementation } \\
\text { of BPR }\end{array}$ & $\begin{array}{l}\text { Implementation } \\
\text { of BSC }\end{array}$ & $\begin{array}{l}\text { Change army } \\
\text { members } \\
\text { commitment }\end{array}$ \\
\hline \multirow{6}{*}{$\begin{array}{l}\text { Spearman's } \\
\text { rho }\end{array}$} & \multirow{2}{*}{$\begin{array}{l}\text { Implementation } \\
\text { BPR }\end{array}$} & $\begin{array}{l}\text { Correlation } \\
\text { Coefficient }\end{array}$ & 1.000 & $.576^{* *}$ & $.587^{* *}$ \\
\hline & & Sig. (2-tailed) & . & .000 & .000 \\
\hline & Implementation of & $\begin{array}{l}\text { Correlation } \\
\text { Coefficient }\end{array}$ & $.576^{* *}$ & 1.000 & $.704^{* *}$ \\
\hline & & Sig. (2-tailed) & .000 & & .000 \\
\hline & & Correlation & $.587^{* *}$ & $.704^{* *}$ & 1.000 \\
\hline & $\begin{array}{l}\text { Commitment change } \\
\text { Army commitment }\end{array}$ & $\begin{array}{l}\text { Coefficient } \\
\text { Sig. (2-tailed) }\end{array}$ & .000 & .000 & . \\
\hline
\end{tabular}

**. Correlation is significant at the 0.01 level (2-tailed). $\mathrm{N}=150$

Source: Field survey, 2019

As can be seen from Table 4.6, the association between the BP,BSC implementation and commitment of change army in organization is statistically significant because the $\mathrm{P}<.000$ and their relationship is positive . There is a moderate positive relationship between BPR, BSC and change army at correlation coefficient 0.576 and $\mathrm{a}<.000$. While strong positive association of BSC and change army the correlation coefficient is 0.704 and a $p<.000$. This means that the increase the commitment of change army members in public organization then, better implementation of BPR and BSC in organization then less commitment change army in organization. This indicate that as the commitment of change army increase the BSC and BPR better achieved the intended purpose in the organizations.

\section{Reference}

ADB(African Development Bank),(2009) Country Governance profile: Federal Democratic Republic of Ethiopia. Addis Ababa .

Adebabay A.(2011). Promoting and strengthening professionalism in the civil service. The Ethiopian case. Addis Ababa, United Nations.

Adejumobi A.S, (2007).The history of Ethiopia. London: Greenwood Press.

Balanced Scorecard Institute,(2012).How Balanced Scorecard can help your organization (online).North Carolina.USA: (Accessed April,2018)

DeWaal A,(2013). Strategic performance management. Second edition. Palgrave Macmillan publisher, England.

ETU (Education and Training Unit),(2013). Education and training : The developmental state. Retrieved from htt://ww.etu.org.za \{Accessed 28 January 2018\}

Evans, A. (2008). Civil service and Administrative reform: Thematic paper. IEG working paper 2008/8.washington D.C world Bank.

Fikadu H ,(2009) Evaluation of the performance of CBE: A balanced scorecard Approach: A research thesis prepared for partial fulfillment of the requirement MA degree in accounting and finance.

Hagerbigegn \& Baro, (2016).Supply and Demand Sides of Public Service Delivery in Oromia Regional State ,Ethiopia the International Journal Of Business \& Management (ISSN 2321-8916)www.theijbm.con Vol 4 Issue 10(accessed January 18/2018) 
Israel Glenn D, (1992. Sampling the Evidence of extension program impact . Program Evaluation and organizational Development, IFAS, University of Florida. PEOD 5.Ocrober.

Kaplan R.S. \&Norton D.P,(1996).Balanced Scorecard : Translating Strategy into Action, Harvard Business School Press.

Kaplan R.S.\& Norton D.P,(2007). Using the balanced scorecard as a strategic management system, Harvard Business Review.

Kothari, (2004).Research Methodology: Methods and Techniques New Age International.

Lane, J.E 2000 .new public management. London: Rout ledge.

Marcus H.G,(1994).A history of Ethiopia Los Angeles, CA: University of California press.

Ministry of capacity building (Mocs).(2007)Business process Reengineering : Training manual Unpublished

MoCS,(2012)Civil service Reform program In Ethiopia Overview with special Emphasis on civil service reform program.

Niven P.R ,(2006). Balanced scorecard step-by step: Maximizing performance and

Ofcancksy,T,P \&Berry.LL,(2004). Ethiopia: A country study. New York: Kissinger.

Paulos C,(2001). The challenges of the civil service reform in Ethiopia: Initial observations eastern Africa Social Science Research Review(EASSRR),13(1):79-103.

Public service College of Oromia, (2015). The $4^{\text {th }}$ Annual Research Symposium on Ensuring institutional transformation to advance Ethiopia renaissance: Public service college of Oromia. Website: www.psco.edu.et ( Accessed august 2018)

Taffasse M. (2008).The Ethiopian Civil Service Reform programme . In T. Assefa(ed). Digest of Ethiopia-s national policies ,strategies and programmes. Addis Ababa .BSPP.

Tesfaye \& Atakity,(2011). The design and implementation of business process reengineering in Ethiopia public sector: An Assessment of all organization, Addis Ababa

Tilaye, (2007) .Civil Service Reform in Ethiopia : Achievements, Problems and possible Solution. Proceedings of the first National Conference on the Achievements. Challenges and Prospects of the Civil service Reform program Implementation in Ethiopia ,Addis Ababa May 31-June 1,2007

UNECA(united Nations Economic Commission for Africa).(2009) .African Governance report II

World Bank World Bank ,(2013).Implementation completion and results Report: To the Federal Democratic Republic of Ethiopia: For a Public sector capacity Building program support project.

Zewdie. B, (1991).A History of modern Ethiopia: 18-1974. Addis Ababa Addis Ababa University.

\section{AUTHOR BIOGRAPHIES}

Assefa Abu Geru is a lecturer at Oromia State University in School of Governance and leadership. He also head of Vice president of administrative and students affairs office in Oromia State University. He completed an MA degree in public management from Ethiopia Civil Service University in 2017 and holds a bachelor's degree in Human Resource Management and Leadership from Oromia State University. His research interests are in the areas of change Management, good governance and strategic management 